and serial feature-positive discrımınations. Animal Learning \& Behavior, 9, 293-303.

Ross, R. T., \& Holland, P. C (1982). Serial positive patternıng: Implications for "occasion setting." Bulletin of the Psychonomic Society, 19, 159-162

Ross, R. T., \& LoLordo, V. M. (1986). Blocking during serial featurepositive discriminations: Assocratuve versus occasion-setting functions. Journal of Experimental Psychology: Animal Behavior Processes, 12, 315-324

Ross, R. T., Orr, W. B., Holland, P. C., \& Berger, T. W. (1984).
Hippocampectomy disrupts acquisition and retention of learned conditional responding. Behavioral Neuroscience, 98, 211-225.

SKINNER, B. F. (1938). The behavior of organisms New York Appleton-Century

TRAPOLD, M. A. (1970). Are expectancies based upon different positıve reınforcıng events discrıminably different? Leaming \& Motivation, 1, 129-140

(Manuscript received July 8, 1988;

revision accepted for publication October 25, 1988.)

\title{
Announcement
}

\section{9th Annual Meeting of the Society for Computers in Psychology \\ Atlanta, Georgia \\ November 16, 1989}

The 19th Annual Meeting of the Society for Computers in Psychology will be held at the Hyatt Regency Hotel in Atlanta, Georgia on November 16, 1989. As usual, this meeting will feature papers on applications of computers to all areas of psychology-experimental, clinical, and educational.

For further information, contact Paula Goolkasian, Department of Psychology, University of North Carolina at Charlotte, Charlotte, NC 28223. 